\title{
Are soft-sediment communities stable? An example from a windy harbour
}

\author{
S. J. Turner, S. F. Thrush, R. D. Pridmore, J. E. Hewitt, V. J. Cummings, M. Maskery \\ National Institute of Water and Atmospheric Research, PO Box 11-115, Hamilton, New Zealand
}

\begin{abstract}
The macrobenthic soft-sediment communities at 6 sites in Manukau Harbour, New Zealand, have been quantitatively sampled at bimonthly intervals since October 1987. Univariate (contingency-table analysis, Kendall's coefficient of concordance and Jaccard's similarity index) and multivariate (non-metric multi-dimensional scaling and canonical community ordinationj analyses were used to assess the absolute and relative structural stability of the communities at each of the 6 sites over the first $5 \frac{1}{2}$ yr of sampling. Despite short-term, seasonal and inter-annual variability, the communities have generally been persistent, in terms of their overall community structure, over the duration of the sampling programme. Manukau Harbour is a dynamic and rigorous environment in terms of movement of water and sediments. Mean wind conditions were found to play an important role in contributing to variability in community structure at different sites in the Harbour, probably as a result of sediment disturbance by wind-induced waves and bottom turbulence. In addition to local factors, there was also evidence that factors operating at harbour-wide scales (e.g. water temperature) contributed to variability in community structure. The populations of some species exhibited marked temporal fluctuations Major recruitment events potentially lead to altered physical, chemical or biological characteristics of the benthic habitat with concomitant effects on other species in the community. Despite the physically and biologically dynamic environment, the communities were persistent and exhibited both resistance. and resilience to physical disturbance and major recruitment events. Other studies have reported these to be important factors contributing to instability in the structure of soft-sediment communities.
\end{abstract}

KEY WORDS: Soft-sediment communities - Stability $\cdot$ Persistence $\cdot$ Variability $\cdot$ Physical disturbance

\section{INTRODUCTION}

Shallow-water coastal and estuarine macrobenthic soft-sediment communities are subject to a variety of physical and biological disturbances which vary in frequency and intensity, as well as temporal and spatial extent. The structure (i.e. species composition and relative species abundances) of these communities, and consequently their stability, may vary markedly in response to these disturbances. Major changes in the structure of benthic communities, and correspondingly their stability, have been attributed to unusual climatic events including major storms leading to physical disturbance of the sediment (e.g. Eagle 1975, Rachor \& Gerlach 1978, Dörjes et al. 1986), floods and droughts (e.g. Cloern \& Nichols 1985, Nichols \& Thompson 1985 , Jones 1987), unusually high or low temperatures (e.g.
Buchanan \& Moore 1986, Dörjes et al. 1986, Beukema 1989, 1992), El Niño events (Tarazona et al. 1988), as well as the highly variable success or failure of larval settlement and post-settlement survival of recruits (e.g. Davis \& VanBlaricom 1978, Stull et al. 1986) Given this potential for disturbance to influence the stability of macrobenthic communities, the identification of temporally consistent patterns is important, not only in addressing issues fundamental to ecology, but also for the conservation and management of coastal resources.

Stability is not a simple characteristic of a community, but rather a multiplicity of distinct attributes (Putman \& Wratten 1984). Theoretical and empirical ecologists have used the term stability to mean at least 5 different things: stability in the strict mathematical sense, persistence, variability, resilience and resis- 


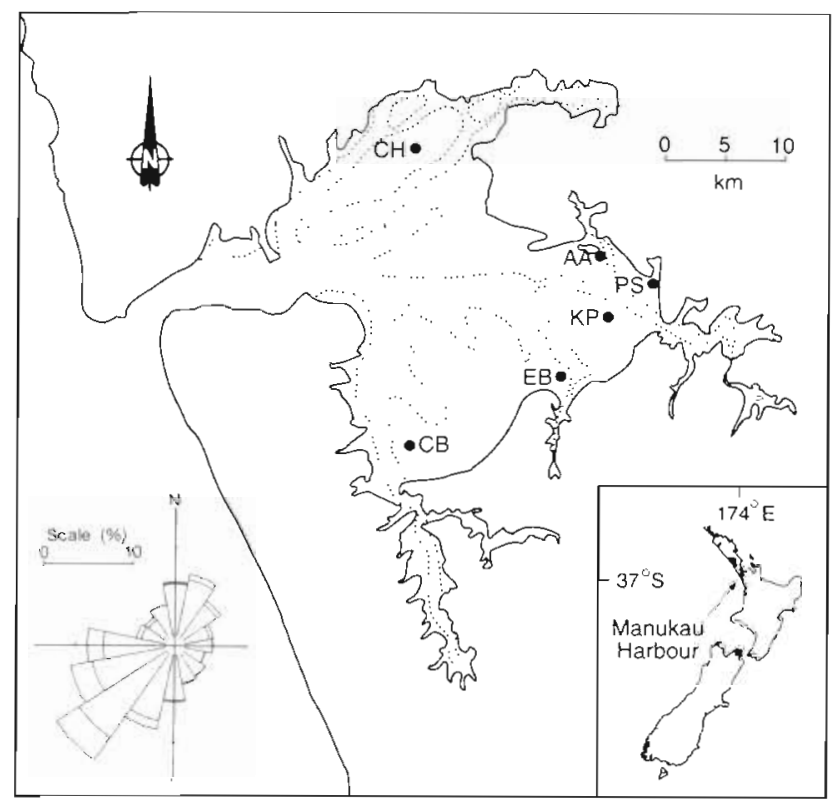

Fig. 1. Manukau Harbour, North Island, New Zealand, showing the location of the 6 sampling sites. Dotted line indicates area of sand-flat exposed at spring low tide. Wind rose data for Auckland International Airport (Manukau Harbour), October 1987 to February 1993; sector $=22.5^{\circ}$, speed increment $=10.0 \mathrm{~m} \mathrm{~s}^{-1}$

tance (e.g. Holling 1973, Connell \& Sousa 1983, Begon et al. 1986, Underwood 1989, Pimm 1991). Persistence can be defined as the constancy in some parameter (e.g. number of species, taxonomic composition, size of a population) of the system over time; variability is the degree to which a parameter fluctuates over time; resilience refers to the ability of a system to recover and continue functioning after disturbance; and resistance describes the ability of the system to withstand or resist such perturbation in the first place. Virtually all the data collected on the stability of natural communities has been concerned with persistence stability.

In this paper we present data collected from the first $5 \frac{1}{2}$ yr of a continuing sampling programme undertaken to monitor macrofaunal communities inhabiting the intertidal sand-flats of Manukau Harbour, North Island, New Zealand $\left(37^{\circ} 02^{\prime} \mathrm{S}, 174^{\circ} 41^{\prime}\right.$ E) (Fig. 1). The data are used to describe patterns of temporal variability in community structure and dynamics, community persistence over the duration of the sampling period, as well as the resilience and resistance of these communities to major natural physical disturbance and recruitment events. We specifically assess changes in community structure and stability in relation to both site-specific and harbour-wide variations in weather conditions, as well as to major changes in the abundance of individual species populations.

\section{MATERIALS AND METHODS}

Field sites and methods. Manukau Harbour is a large $\left(340 \mathrm{~km}^{2}\right)$ shallow inlet, located on the west coast of the North Island, New Zealand (Fig. 1). Extensive intertidal sand-flats are a major feature of the Harbour, comprising about $40 \%\left(145 \mathrm{~km}^{2}\right)$ of its area. The macrobenthic infaunal communities of these sand-flats play an important role in the overall ecology of the Harbour (Pridmore et al. 1990).

Six permanent sites [AA (Auckland Airport), CB (Clarks Beach), CH (Cape Horn), EB (Elletts Beach), KP (Karaka Point), PS (Puhinui Spit)], each of $9000 \mathrm{~m}^{2}$, were established at approximately mid-tide level on sand-flats around the Harbour (Fig. 1). The sampling sites were chosen as being characteristic and representative of the intertidal sand-flat habitats in the Harbour and were selected for their similarity in terms of overall physical appearance and near-surface sediment composition (i.e. predominantly fine sand; Pridmore et al. 1990). Repeated observations at all the sites indicate that sediment composition was consistent over the duration of the sampling programme (authors' unpubl. obs.). Sorting coefficients at all the sites were typical of moderately to very well sorted sediments, suggesting low within-site variability in near-surface sediment grain size (Pridmore et al. 1990)

The sampling design and its justification are presented in detail in Pridmore et al. (1990), Hewitt et al. (1993) and Thrush et al. (1994). Briefly, each site was divided into 12 equal sectors ( $25 \times 30 \mathrm{~m}$ area), and on each sampling occasion 1 core sample $(13 \mathrm{~cm}$ diameter and $15 \mathrm{~cm}$ depth) was taken from every sector. After collection, the samples were sieved through a $0.5 \mathrm{~mm}$ mesh, and fixed in 5\% formalin and $0.1 \%$ Rose Bengal in seawater. All the macrofauna were sorted, identified to the lowest practical taxonomic level (generally species or species group), counted and preserved in $70 \%$ alcohol.

All but one of the sites were sampled at 2 mo intervals (in February, April, June, August, October and December) between October 1987 and February 1993. CB was sampled from December 1987. No sample was collected from any site in October or December 1988.

Data analysis. Three measures of community persistence over the first $5 \frac{1}{2}$ yr of the monitoring programme were calculated for each site. Absolute species' abundances were used to establish whether species' abundances were similar over time ( $r \times s$ contingency-table analysis; Sokal \& Rohlf 1981); abundance rankings were used to assess whether species' ranks were correlated through time (Kendall's coefficient of concordance $W_{\text {i }}$ Sokal \& Rohlf 1981); presence-absence data were used to examine the similarity in community composition through time (Jaccard's similarity index; 
Legendre \& Vaudor 1991). On the first sampling occasion 36 samples were collected from each site (see Pridmore et al. 1990). To provide a comparison with the variability in community composition among a large number of samples collected at one time, Jaccard's similarity index was also calculated for these samples.

The variability in community structure over the duration of the sampling period and the relative persistence of the communities at each site were examined using multivariate analyses. Data were analysed using non-metric multi-dimensional scaling (MDS; using PRIMER: see Field et al. 1982, Clarke \& Green 1988, Clarke 1993), detrended correspondence analysis (using DECORANA: Hill 1979) and correspondence analysis (using CANOCO: Ter Braak 1988). The ordination configurations obtained from the 3 techniques were essentially similar, thus only the results for the MDS ordinations, based on actual species abundances, are presented. The congruent configurations obtained using these dissimilar ordination techniques are a good indication that a realistic ordination has been achieved.

MDS ordinations employing the Bray-Curtis similarity index were undertaken on the untransformed community data for each individual site. Significance testing of seasonal and annual differences between samples was undertaken using the ANOSIM (analysis of similarities) randomisation test based on rank similarities of the samples (Clarke \& Green 1988, Clarke 1993). A MDS ordination was also performed on the square-root transformed community data for all 6 sites combined.

Canonical correspondence analysis (CANOCO) was used to identify relationships between the community ordination and the environmental variables: mean and maximum wind condition, derived from multiplying wind speed by a directional component which took into account the influence of wave fetch and the degree of protection afforded by adjacent sand-banks

Table 1. Univariate measures of community persistence. $\chi^{2}$ : chi-squared analysis of $r \times s$ contingency-tables; df: degrees of freedom; $W$ : Kendall's coefficient of concordance; n: number of species; SI: Jaccard's similarity index; all times: similarity index for all samples over 31 sampling times; time 1: similarity index for 36 samples collected at time 1; ns: not significant, $p>0.05_{i}$ ' significant, $p<0.05$

\begin{tabular}{|c|c|c|c|c|c|c|}
\hline \multirow[t]{2}{*}{ Site } & \multicolumn{2}{|c|}{ Absolute abundance } & \multicolumn{2}{|c|}{ Abundance ranking } & \multicolumn{2}{|c|}{ Presence/absence } \\
\hline & $\chi^{2}$ & $\mathrm{df}$ & $W$ & $\mathrm{n}$ & SI all times & SI time 1 \\
\hline $\mathrm{AA}$ & 1203 & $2370 \mathrm{~ns}$ & 0.526 & $80 \mathrm{~ns}$ & 0.569 & 0.517 \\
\hline CB & 2175 & $3567 \mathrm{~ns}$ & 0.533 & $124 \mathrm{~ns}$ & 0.541 & 0.404 \\
\hline $\mathrm{CH}$ & 6040 & $3510^{\bullet}$ & 0.467 & $118 \mathrm{~ns}$ & 0.453 & 0.303 \\
\hline$E B$ & 1924 & 2340 ns & 0.509 & $79 \mathrm{~ns}$ & 0.469 & 0.450 \\
\hline KP & 2103 & $3120 \mathrm{~ns}$ & 0.480 & $105 \mathrm{~ns}$ & 0.422 & 0.375 \\
\hline PS & 2017 & $2520 \mathrm{~ns}$ & 0.556 & $85 \mathrm{~ns}$ & 0.475 & 0.392 \\
\hline
\end{tabular}

(wind data from Auckland International Airport Weather Station, NIWA Environmental Data); and mean and maximum water temperature (data from Auckland Regional Council 1994).

\section{RESULTS}

\section{Patterns of variability in abundance and community composition}

The seasonal and annual variations in the total number of individuals and species present in the community at each site are shown in Figs. 2 \& 3 respectively. The contributions of the 3 major taxonomic groups (polychaetes, molluscs and crustaceans) to the total number of individuals and species are also shown in Figs. $2 \& 3$. There was marked temporal variability of both the numbers of individuals and species, as well as the taxonomic composition of the communities, at each site. The timing and magnitude of the fluctuations varied among the different taxonomic groups, both from one year to the next and between different sites.

At some sites there was also evidence of consistent longer-term (i.e. greater than annual) trends in the total number of individuals and species, as well as the taxonomic composition of the communities. For example, there was an increase in the total number of individuals recorded at CB between 1987 and 1993, which can be attributed primarily to an increase in the numbers of polychaetes (Fig. 2).

\section{Univariate measures of community persistence}

Communities where the average similarity index based on presence-absence data is $<0.60$ can generally be considered to have experienced measurable changes in their species composition (Rahel 1990). On the basis of the presence-absence data, the communities at the 6 sites would therefore be considered as non-persistent (Table 1). However, comparison with the average similarity documented among the 36 samples collected at each site at the start of this study suggests that there was greater similarity among the samples collected at each of the sites over time than among the samples collected at each site at the start. The communities at $A A, C B, E B, P S$ and $K P$ can thus be judged as relatively persistent at all 3 levels of community resolution (species abundances, abundance rankings and species presence-absence) (Table 1). The 

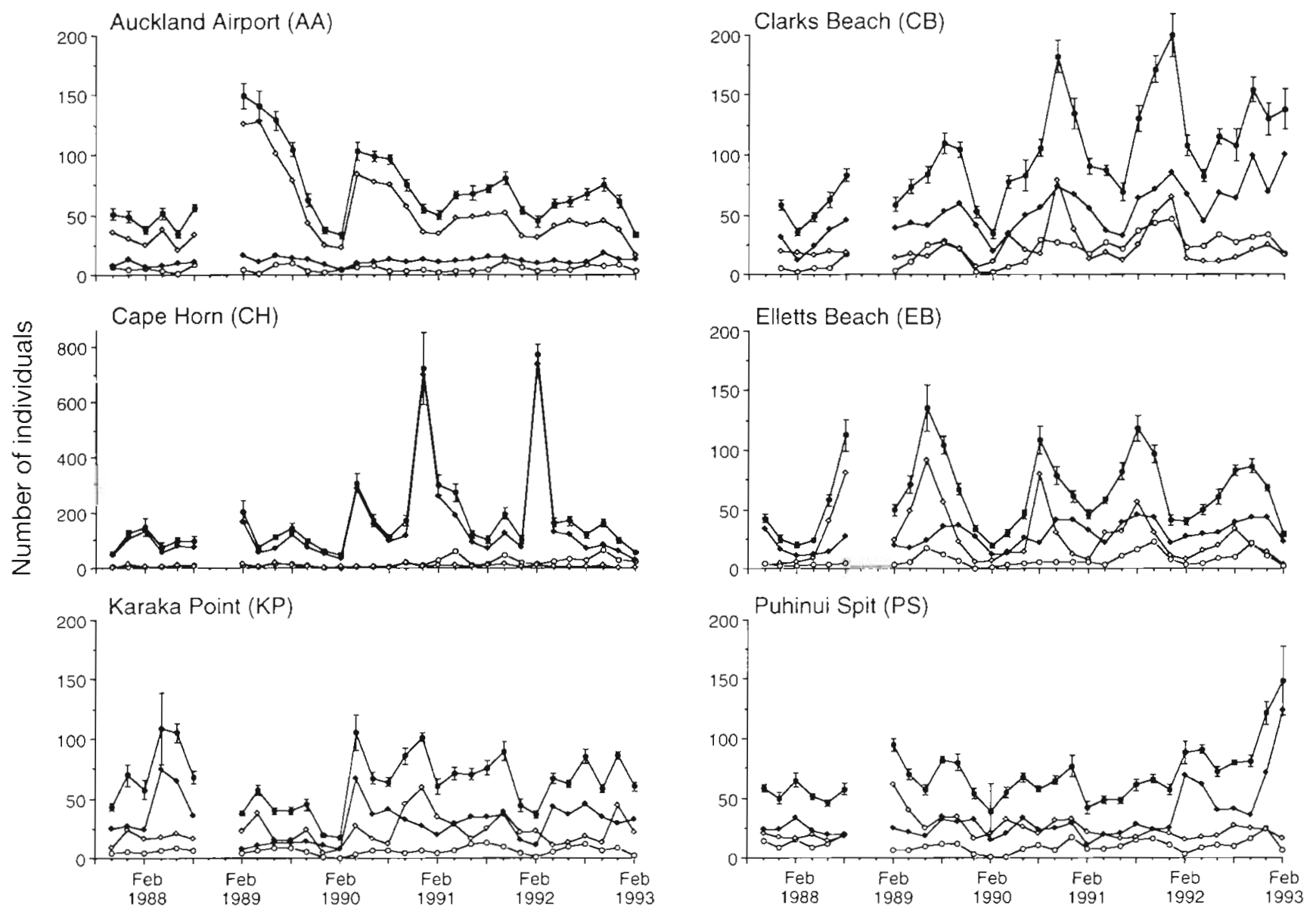

Time

Fig. 2. Temporal variation in the mean ( \pm standard error) total number of individuals and the mean number of polychaetes, molluscs and crustaceans in the communities at 6 sites in Manukau Harbour from October 1987 to February 1993. Data for the less abundant taxonomic groups (e.g. echinoderms) are included in the total values but are not presented separately. No samples were collected in October or December 1988

same species were generally found at each site (i.e. local extinctions and colonizations were of infrequent occurrence), and their absolute abundances, as well as their abundance rankings, remained relatively constant over the duration of the monitoring period. At $\mathrm{CH}$, the absolute species abundances, but not the abundance rankings or species presence-absence, varied significantly over time (Table 1).

\section{Non-metric MDS ordinations}

The MDS ordinations for the communities at the 6 sites are given in Fig. 4. The MDS plots show that at each site some changes in community structure occurred between the sampling periods and from year to year For example, the communities at $\mathrm{CB}$ and $\mathrm{CH}$ underwent progressive, directional changes in struc- ture, with differences apparent between samples collected at the beginning of the monitoring period and those collected at later dates. Conversely, the ordination for AA shows a cyclic change in community structure, with the samples collected in the fifth year of the study occupying positions in the ordination space which are closer to those for the first year compared to the intervening years of the study. The relatively low stress levels for the 2-dimensional ordinations of the untransformed mean species abundance data indicate an acceptable representation of the similarities in community structure has been achieved (see Field et al. 1982, Clarke 1993).

Significance testing with ANOSIM indicates that, for most of the sites, seasonal and annual differences in community structure occurred (Table 2). Although most of the differences between the seasons were not significant $(p>0.05)$, there was a general tendency for 

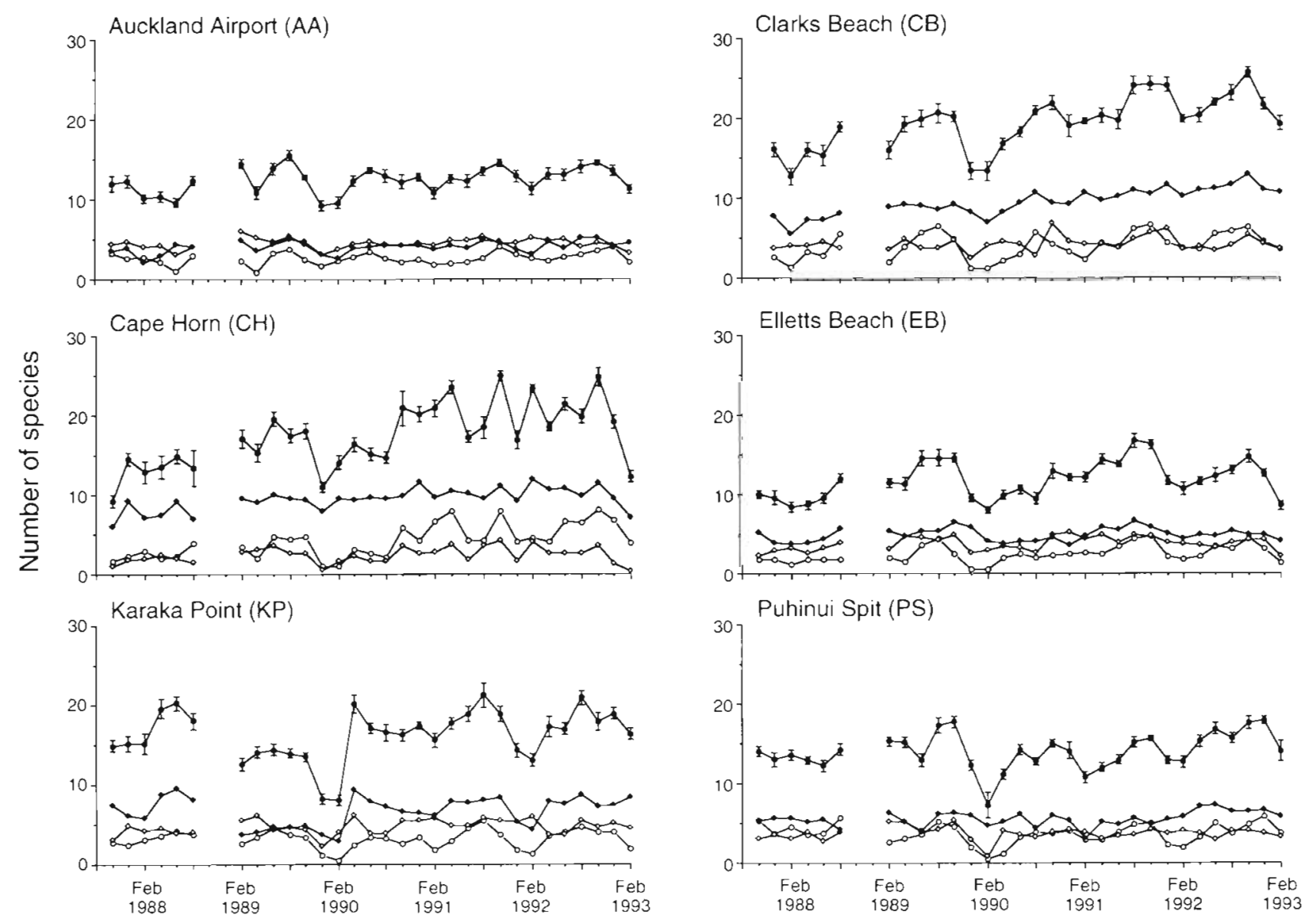

Time

Fig. 3. Temporal variation in the mean ( \pm standard error) total number of species and the mean number of polychaete, mollusc and crustacean species in the communities at 6 sites in Manukau Harbour from October 1987 to February 1993. Data for the less abundant taxonomic groups (e.g. echinoderms) are included in the total values but are not presented separately. No samples were collected in October or December 1988

the communities sampled in the summer months (December and February) to be dissimilar to those sampled in the winter months (June and August), with April and October samples dissimilar to each other and the other months (Table 2). Thus, significant differences in community structure occurred at AA between February and June or August, April and August or October, as well as between October and June. At CB, significant differences occurred between June and December and between February and June or August. Significant differences between August and December or February and October and June occurred at KP, and between August and February or April, as well as April and October at PS. The greatest number of significant differences in community structure were reported at EB, where the February samples were significantly different from all but the December samples. There were also significant differences between the April and
October, and June and December samples at this site. $\mathrm{CH}$ was the only site where community structure did not differ significantly on a seasonal basis. This is attributable to major annual fluctuations in the seasonal abundance of individual species populations increasing the total variance over the study period (Fig. 2).

Annual differences identified with ANOSIM indicate that there was continual change in community structure over the duration of the study, with consecutive years generally being more similar in structure than non-consecutive years (Table 2). At EB, for example, community structure in year 1 (1988) was similar to that in year 2 , but dissimilar to that in subsequent years; in year 2 , community structure was similar to that in years 1 and 3 ; in year 3 , to that in years 2 and 4 ; in year 4 , to that in years 3 and 5 ; while in year 5, community structure was similar to that in year 4 but significantly dissimilar to that in earlier years. At CB and 
(a) Auckland Airport (AA)

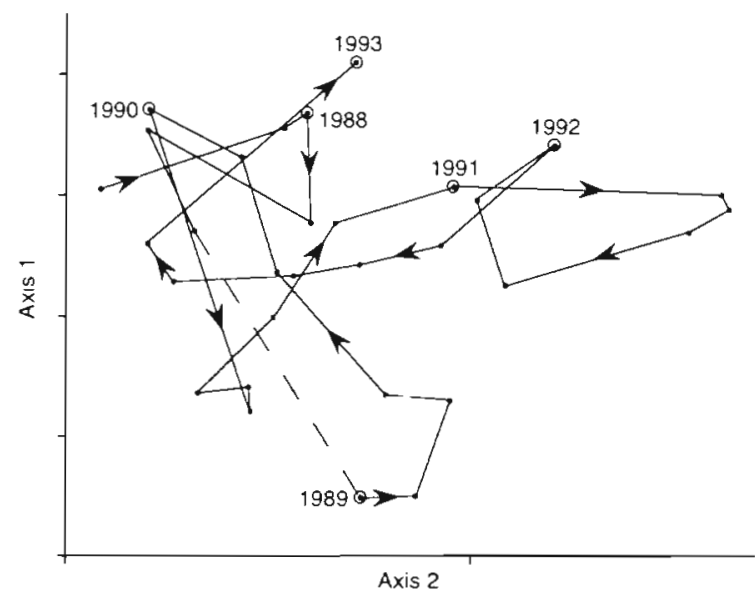

(c) Cape Horn $(\mathrm{CH})$

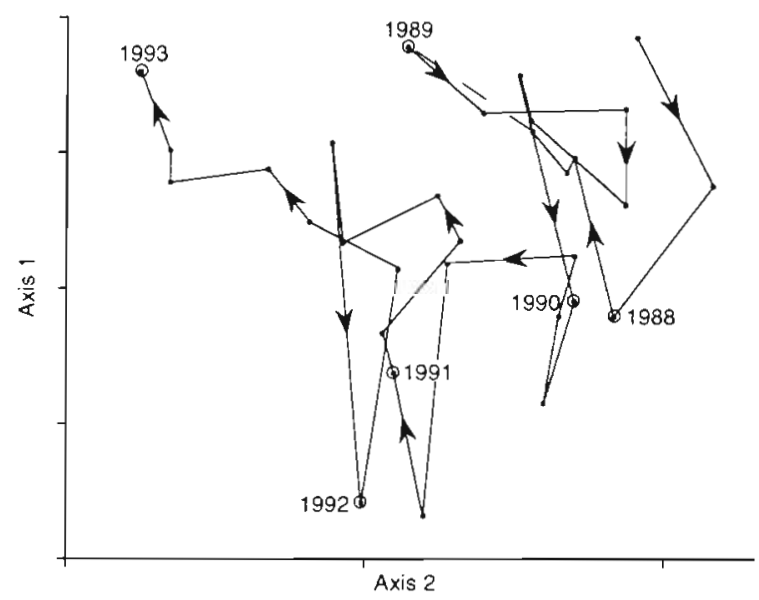

(e) Karaka Point (KP)

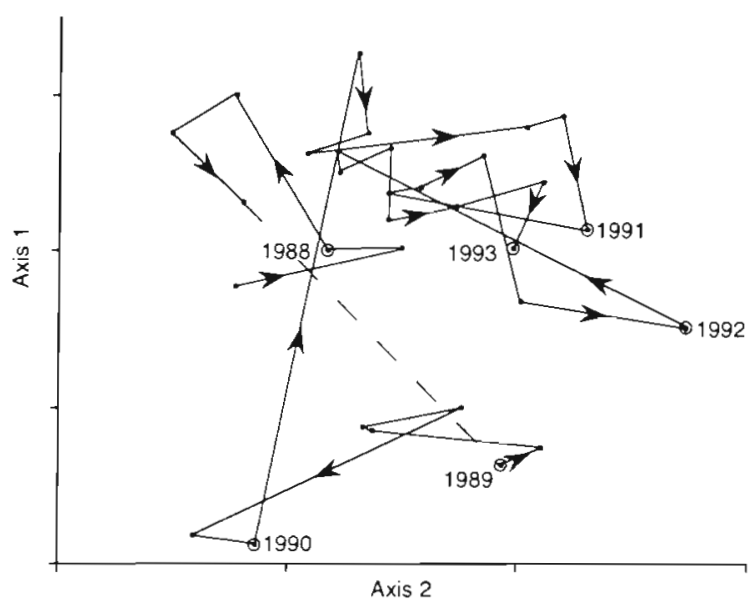

(b) Clarks Beach (CB)

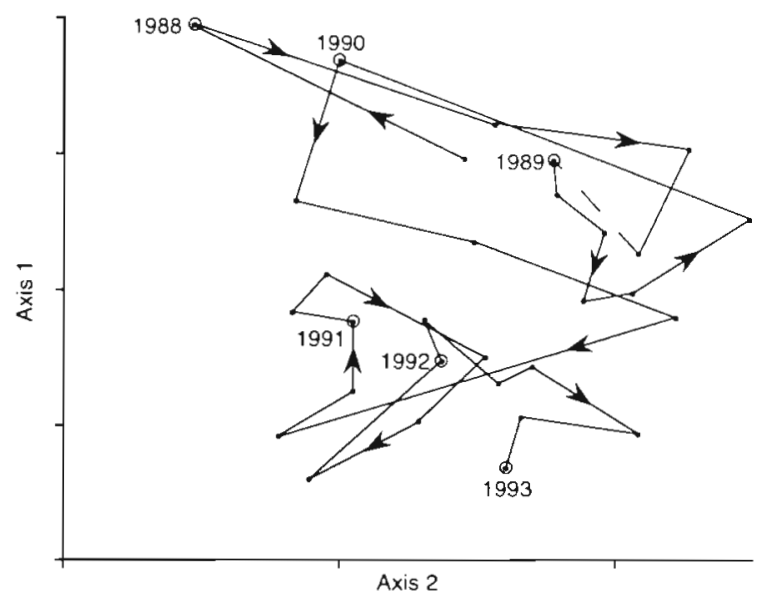

(d) Elletts Beach (EB)

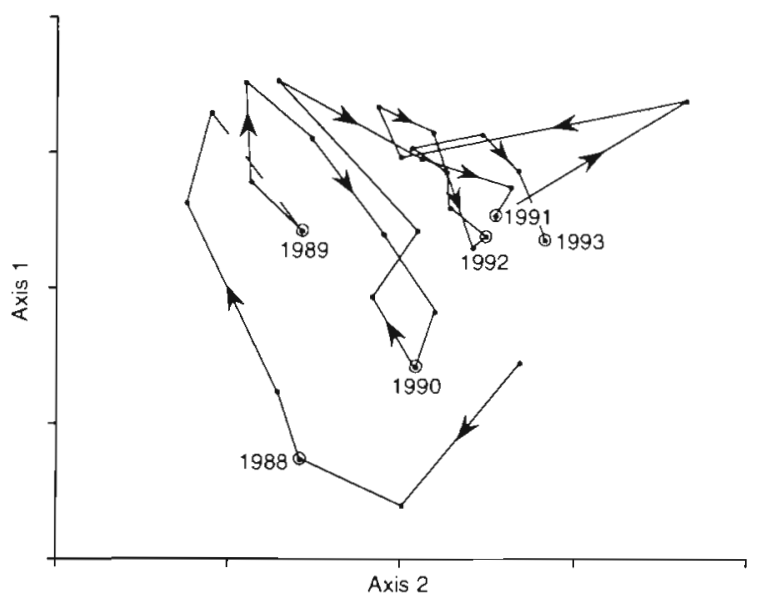

(f) Puhinui Spit (PS)

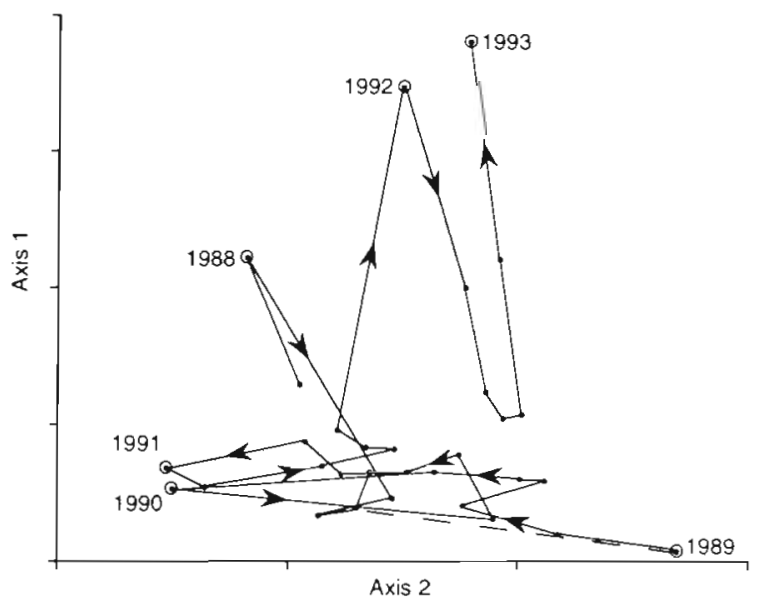

Fig. 4. Multi-dimensional scaling ordinations of untransformed community data for each site in Manukau Harbour, at each time between October 1987 and February 1993. The points are connected in time sequence; the broken line joins samples collected in August 1988 and February 1989, no samples were collected in October or December 1988 . Axis values are purely arbitrary and are not given. Stress values for the 2-dimensional ordinations are: (a) $\mathrm{AA}=0.110$, (b) $\mathrm{CB}=0.154$, (c) $\mathrm{CH}=0.099$, (d) $\mathrm{EB}=$ 0.131 , (e) $K P=0.126$, (f $)$ PS $=0.127$ 
Table 2. Summary of pairwise significances of ANOSIM comparisons of months and years. ns: not significant, $p>0.05$

\begin{tabular}{|c|c|c|c|c|c|c|}
\hline \multicolumn{3}{|c|}{ Comparison of months } & \multirow[b]{2}{*}{ Dec } & \multirow[b]{2}{*}{ Feb } & \multirow[b]{2}{*}{ Apr } & \multirow[b]{2}{*}{ Jun } \\
\hline Site & & Oct & & & & \\
\hline \multirow[t]{5}{*}{ A.A } & Dec & ns & & & & \\
\hline & Feb & ns & ns & & & \\
\hline & Apr & $5 \%$ & ns & ns & & \\
\hline & Jun & $5 \%$ & ns & $5 \%$ & ns & \\
\hline & Aug & ns & ns & $5 \%$ & $1 \%$ & ns \\
\hline \multirow[t]{5}{*}{ CB } & Dec & ns & & & & \\
\hline & Feb & ns & $\mathrm{ns}$ & & & \\
\hline & Apr & ns & ns & ns & & \\
\hline & Jun & ns & $5 \%$ & $5 \%$ & ns & \\
\hline & Aug & ns & $\mathrm{ns}$ & $5 \%$ & ns & ns \\
\hline \multirow[t]{5}{*}{$\mathrm{CH}$} & Dec & ns & & & & \\
\hline & Feb & ns & ns & & & \\
\hline & Apr & ns & ns & $\mathrm{ns}$ & & \\
\hline & Jun & ns & ns & ns & ns & \\
\hline & Aug & ns & ns & ns & ns & ns \\
\hline \multirow[t]{5}{*}{ EB } & Dec & ns & & & & \\
\hline & Feb & $5 \%$ & ns & & & \\
\hline & Apr & $5 \%$ & $\mathrm{~ns}$ & $5 \%$ & & \\
\hline & Jun & $\mathrm{ns}$ & $5 \%$ & $1 \%$ & ns & \\
\hline & Aug & ns & ns & $1 \%$ & ns & ns \\
\hline \multirow[t]{5}{*}{$\mathrm{KP}$} & Dec & ns & & & & \\
\hline & Feb & ns & ns & & & \\
\hline & Apr & ns & ns & ns & & \\
\hline & Jun & $5 \%$ & ns & ns & ns & \\
\hline & Aug & ns & $5 \%$ & $5 \%$ & ns & ns \\
\hline \multirow[t]{5}{*}{ PS } & Dec & ns & & & & \\
\hline & Feb & ns & ns & & & \\
\hline & Apr & $5 \%$ & ns & ns & & \\
\hline & Jun & $\mathrm{ns}$ & ns & $\mathrm{ns}$ & $\mathrm{ns}$ & \\
\hline & Aug & ns & ns & $5 \%$ & $5 \%$ & ns \\
\hline \multicolumn{7}{|c|}{ Comparison of years } \\
\hline Site & & 1988 & 1989 & & 1990 & 1991 \\
\hline \multirow[t]{4}{*}{ AA } & 1989 & $5 \%$ & & & & \\
\hline & 1990 & $5 \%$ & ns & & & \\
\hline & 1991 & $1 \%$ & $5 \%$ & & $5 \%$ & \\
\hline & 1992 & $5 \%$ & ns & & ns & $1 \%$ \\
\hline \multirow[t]{4}{*}{$\mathrm{CB}$} & 1989 & ns & & & & \\
\hline & 1990 & $1 \%$ & $1 \%$ & & & \\
\hline & 1991 & $1 \%$ & $1 \%$ & & ns & \\
\hline & 1992 & $1 \%$ & $1 \%$ & & $1 \%$ & ns \\
\hline \multirow[t]{4}{*}{$\mathrm{CH}$} & 1989 & ns & & & & \\
\hline & 1990 & $1 \%$ & $5 \%$ & & & \\
\hline & 1991 & $5 \%$ & $5 \%$ & & ns & \\
\hline & 1992 & $1 \%$ & $1 \%$ & & $1 \%$ & ns \\
\hline \multirow[t]{4}{*}{ EB } & 1989 & ns & & & & \\
\hline & 1990 & $1 \%$ & $n s$ & & & \\
\hline & 1991 & $1 \%$ & $5 \%$ & & ns & \\
\hline & 1992 & $1 \%$ & $1 \%$ & & $1 \%$ & ns \\
\hline \multirow[t]{4}{*}{ KP } & 1989 & $1 \%$ & & & & \\
\hline & 1990 & $1 \%$ & $1 \%$ & & & \\
\hline & 1991 & $1 \%$ & $1 \%$ & & ns & \\
\hline & 1992 & $1 \%$ & $1 \%$ & & $5 \%$ & ns \\
\hline PS & 1989 & $1 \%$ & & & & \\
\hline & 1990 & $1 \%$ & $\mathrm{~ns}$ & & & \\
\hline & 1991 & $5 \%$ & $5 \%$ & & ns & \\
\hline & 1992 & $1 \%$ & $1 \%$ & & $1 \%$ & $5 \%$ \\
\hline
\end{tabular}

$\mathrm{CH}$, significant differences in community structure also occurred between years 2 and 3 ; at KP between years 1 and 2 , and years 2 and 3 ; and at PS between years 1 and 2 and years 4 and 5 . Thus, at these sites the greatest amount of change in community structure generally occurred at the beginning and middle of the monitoring programme, with communities appearing more similar in structure in the later years. The exception was AA, where there were no significant differences in community structure between years 2 and 3 and year 5 , suggesting that a cyclical change in structure has occurred.

\section{Pooled MDS ordination}

A MDS ordination was performed on the square-root transformed community data for all 6 sites combined (Fig. 5). Despite the variability in composition evident in the individual MDS ordinations for each site (Fig. 4), the pooled MDS configuration reveals consistent differences in community structure between $\mathrm{AA}, \mathrm{CB}, \mathrm{CH}$, $\mathrm{EB}$ and PS. The communities at these sites have maintained distinctly different species compositions and abundances, and there is no evidence for changes in the fundamental community structure characteristic of these sites. The community at KP was not so discrete or consistent in structure, exhibiting similarities to the communities at CB, EB and PS at different times during the $5 \frac{1}{2} 2$ yr period.

The relative magnitude of total compositional change over the sampling period, as indicated by the

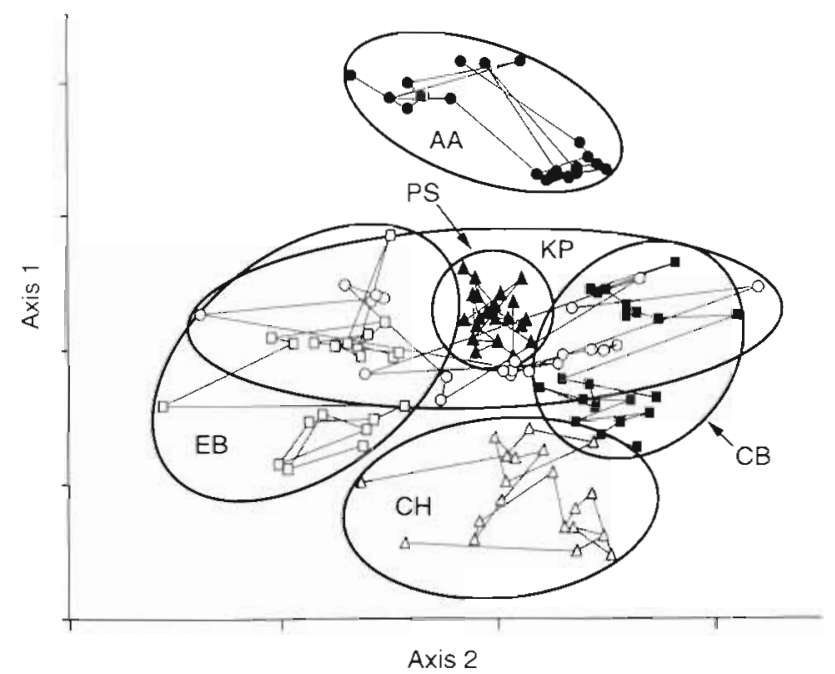

Fig. 5. Multi-dimensional scaling ordination of square-root transformed community data for all sites in Manukau Harbour, at each time between October 1987 and February 1993. Axis values are purely arbitrary and are not given. Stress value $=0.166$ 
extent of migration of the community in the ordination space, provides a comparative measure of the variability and persistence of each community. This was quantified using the standard deviation of the distance to the centroid of the cluster of points representing each site in the 2-dimensional ordination space (Table 3 ). The standard deviations indicate that the communities exhibited different degrees of variability and thereby also persistence. The communities at $\mathrm{CB}$ and PS were the least variable or most persistent in composition, showing the smallest change in their position in the ordination space during the $5 \frac{1}{2}$ yr of the study. In contrast, the greatest amount of variation in community structure occurred at AA, CH, EB and KP.

To relate these variations in the ordination space to actual changes in community structure, the points of maximum divergence in the ordination space for each site in Fig. 5 were selected. The mean abundances of the 8 top-ranked species in the samples at these times are presented in Table 4 . The differences in community structure at different sampling times were a reflection of the fluctuating species' abundances. However, even at times of maximum variability in community structure, between 2 and 5 of the highest-ranked species were common to the communities. There is thus no evidence for complete turnover of the topranked species in any of the communities.

Table 3. The centroid of the cluster of points representing each site in the 2-dimensional ordination in Fig. 5 and the standard deviation of the distances to the centroid from the points in the cluster for each site

\begin{tabular}{|lcc|}
\hline Site & Centroid & SD \\
\hline AA & 1.50 & 0.33 \\
CB & 0.73 & 0.19 \\
CH & 1.20 & 0.32 \\
EB & 0.88 & 0.32 \\
KP & 0.56 & 0.31 \\
PS & 0.22 & 0.12 \\
\hline
\end{tabular}

\section{Canonical correspondence analysis (CANOCO)}

The solution of the CANOCO is presented in Fig. 6. Maximum wind condition and mean and maximum water temperature were all poorly correlated with their respective axes (axis 1, $r=0.59$; axis $3, r=-0.57$; axis $4, r=0.30$ ) and thus contributed relatively little to explaining the differences in community structure at each site. The poor correlation between maximum wind and the major explanatory axis $148.9 \%$ of the variance was accounted for by axis 1 ) is indicative that other factors are necessary to explain some of the between-site differences in community structure le.g.

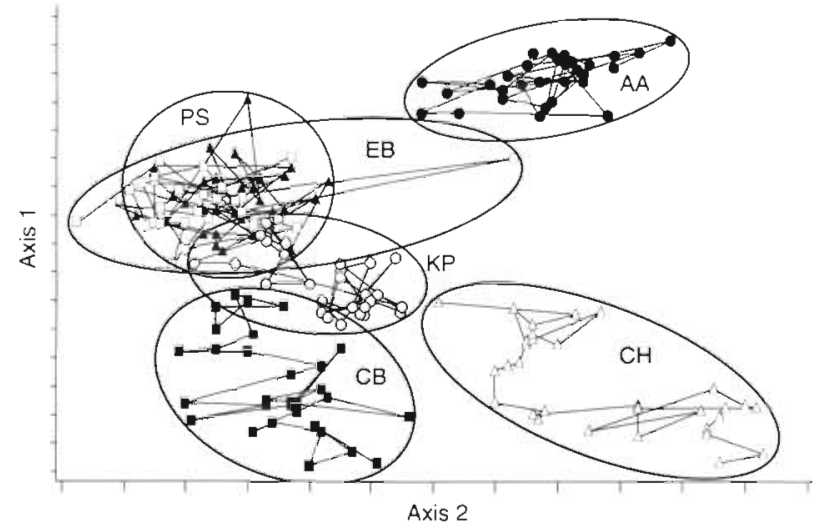

Fig. 6. Canonical correspondence analysis ordination of untransformed community data for all sites in Manukau Harbour, at each time between October 1987 and February 1993

the differences between the bivalve-dominated community at $\mathrm{AA}$ and the polychaete-dominated community at $\mathrm{CH}$ ). Axis 2, which accounted for $36.7 \%$ of the variance, was strongly correlated with mean wind conditions $(r=0.80)$. The position of each site along axis 2 in the ordination space can thus be related to the location of the sites along an environmental gradient generated by mean wind. The sites were clearly separated along this axis into those where community structure was most affected by mean wind, namely $\mathrm{AA}$ and $\mathrm{CH}$, and communities at $C B, E B, K P$ and PS, which were less affected by mean wind (Fig. 6).

\section{DISCUSSION}

\section{Evaluation of community persistence and variability}

The detection of community stability does not require that a community remain unchanged, but rather that the observed change in structure is not larger than can normally be expected to occur given the natural temporal and spatial variability of the populations. Thus, if we are to demonstrate that a community exhibits persistence, there is a need for an objective evaluation of how much variation in structure a community can exhibit, while preserving a certain recognisably similar structure. A community can be regarded as most stable when the absolute abundance of each species remains constant over time, and least stable conditions occur when even the presence or absence of component species is unpredictable over time; i.e. local extinctions and colonizations are of frequent occurrence (Rahel 1990). At intermediate levels of stability, the absolute abundances of individual species fluctuate, but the same species are always present and their abundance rankings remain constant (Rahel 1990). 
Table 4. Mean number of individuals per core ( \pm standard error) for the 8 top-ranked species in the samples at the points of maximum divergence of the trajectory in the ordination space for each site in Fig. 5. Species common to both sample times are shown in bold

\begin{tabular}{|c|c|c|c|c|c|c|}
\hline Site & Date & Species & Abundance & Date & Species & Abundance \\
\hline \multirow[t]{8}{*}{ A.A } & Feb 1990 & Macomona liliana & $18.5(1.8)$ & Apr 1991 & Nucula hartvigiana & $22.0 \quad(2.6)$ \\
\hline & & Waitangi brevirostris & $2.3 \quad(0.4)$ & & Macomona liliana & $18.3(1.4)$ \\
\hline & & Magelona?dakini & $1.7 \quad(0.4)$ & & Aonides oxycephala & $4.0 \quad(1.7)$ \\
\hline & & Aonides oxycephala & $1.5(0.5)$ & & Magelona?dakini & $3.0 \quad(0.9)$ \\
\hline & & Austrovenus stutchburyi & $1.4 \quad(0.4\}$ & & Austrovenus stutchburyi & $2.8(0.6)$ \\
\hline & & Mactra ovata & $1.3(0.2)$ & & Orbinia papillosa & $2.8 \quad(0.9)$ \\
\hline & & Exosphaeroma spp. & $1.0 \quad(0.3)$ & & Nemerteans & $2.6 \quad(0.6)$ \\
\hline & & Trochodota dendyi & $0.9 \quad(0.3)$ & & Hiatula siliquens & $1.9 \quad(0.4)$ \\
\hline \multirow[t]{9}{*}{$\mathrm{CB}$} & Feb 1988 & Nucula hartvigiana & $9.8(1.5)$ & Feb 1993 & Boccardia syrtis & $34.4 \quad(8.7)$ \\
\hline & & Macomona liliana & $4.5 \quad(0.5)$ & & Macroclymenella stewartensis & $20.3 \quad(2.3)$ \\
\hline & & Magelona ?dakini & $2.9 \quad(0.7)$ & & Sphaerosyllis semiverricosa & $13.4 \quad(3.1)$ \\
\hline & & Heteromastus filiformis & $2.0 \quad(0.6)$ & & Syllis sp. & $10.7 \quad(1.2)$ \\
\hline & & Nemerteans & $1.8 \quad(0.5)$ & & Ostracods & $9.4 \quad(1.9)$ \\
\hline & & Notoacmea helmsi & $1.7(0.6)$ & & Nucula hartvigiana & $8.5(2.1)$ \\
\hline & & Syllis sp. & $1.4(0.6)$ & & Heteromastus filiformis & $7.8 \quad(1.1)$ \\
\hline & & Owenia fusiformis & $1.2(0.3)$ & & Macomona liliana & $5.3(0.5)$ \\
\hline & & Hiatula siliquens & $1.2(0.5)$ & & & \\
\hline \multirow[t]{8}{*}{$\mathrm{CH}$} & Oct 1987 & Heteromastus filiformis & $28.3 \quad(5.0)$ & Feb 1992 & Boccardia syrtis & $618.9(36.2)$ \\
\hline & & Magelona ?dakini & $10.2(1.4)$ & & Sphaerosyllis semiverricosa & $41.0 \quad(6.5)$ \\
\hline & & Macroclymenella stewartensis & $2.4(0.7)$ & & Heteromastus filiformis & $31.5 \quad(2.2)$ \\
\hline & & Goniada emerita & $1.8(0.5)$ & & Euchone sp. & $16.7(1.6)$ \\
\hline & & Nemerteans & $1.0 \quad(0.3)$ & & Nemerteans & $11.6 \quad(1.7)$ \\
\hline & & Mysids & $0.9 \quad(0.6)$ & & Goniada emerita & $8.2(1.0)$ \\
\hline & & Colurostylis lemurum & $0.8(0.4)$ & & Ostracods & $6.3(0.9)$ \\
\hline & & Arthritica bifurca & $0.7 \quad(0.4)$ & & Macroclymenella stewartensis & $4.2 \quad 0.8\}$ \\
\hline \multirow[t]{9}{*}{$\mathrm{EB}$} & Feb 1988 & Heteromastus filiformis & $3.9(1.3)$ & Apr 1991 & Macomona liliana & $18.9(1.1)$ \\
\hline & & Magelona ?dakini & $2.5(0.6)$ & & Aonides oxycephala & $12.1(1.5)$ \\
\hline & & Macomona liliana & $2.4 \quad(0.3)$ & & Austrovenus stutchburyi & $5.9(1.1)$ \\
\hline & & Macroclymenella stewartensis & $2.2(0.7)$ & & Travisia olens var. NZ & $3.2(0.5)$ \\
\hline & & Torridoharpinia hurleyi & $1.3(0.7)$ & & Orbinia papillosa & $2.3 \quad(0.5)$ \\
\hline & & Nucula hartvigiana & $1.1 \quad(0.3)$ & & Hiatula siliquens & $1.8 \quad(0.3)$ \\
\hline & & Lepidodontidae & $1.0 \quad(0.3)$ & & Nemerteans & $1.3(0.4)$ \\
\hline & & Goniada emerita & $0.8 \quad(0.3)$ & & Heteromastus filiformis & $1.3(0.3)$ \\
\hline & & & & & Zeacumantus lutulentus & $1.3(0.4)$ \\
\hline \multirow[t]{8}{*}{$\mathrm{KP}$} & Feb 1990 & Magelona ?dakini & $4.4 \quad(0.9)$ & Apr 1992 & Heteromastus filiformis & $18.9(1.7)$ \\
\hline & & Macomona Iiliana & $2.8 \quad(0.4)$ & & Magelona ?dakini & $7.9 \quad(1.0)$ \\
\hline & & Nucula hartvigiana & $1.8(0.6)$ & & Sphaerosyllis semiverricosa & $5.8(1.2)$ \\
\hline & & Macroclymenella stewartensis & $1.3(0.2)$ & & Nemerteans & $5.2(0.9)$ \\
\hline & & Anthopleura aureoradiata & $1.1(0.4)$ & & Macomona liliana & $4.0 \quad(0.5)$ \\
\hline & & Owenia fusiformis & $1.0 \quad(0.3)$ & & Notoacmea helmsi & $3.5(0.8)$ \\
\hline & & Sypharochiton pelliserpentis & $0.8 \quad[0.2]$ & & Boccardia syrtis & $3.2(1.4)$ \\
\hline & & Notoacmea helmsi & $0.8 \quad(0.4)$ & & Owenia fusiformis & $2.3(0.6)$ \\
\hline \multirow[t]{8}{*}{ PS } & Feb 1988 & Boccardia syrtis & $21.3(5.0)$ & Feb 1991 & Macomona liliana & $9.3(1.2)$ \\
\hline & & Exosphaeroma spp. & $9.8(2.1)$ & & Nucula hartvigiana & $9.3(3.8)$ \\
\hline & & Macomona liliana & $9.8 \quad(0.9)$ & & Heteromastus filiformis & $7.6(1.6)$ \\
\hline & & Nucula hartvigiana & $4.7(1.4)$ & & Exosphaeroma spp. & $3.7 \quad(0.7)$ \\
\hline & & Heteromastus filiformis & $4.6 \quad(0.9)$ & & Waitangi brevirostris & $2.2(0.9)$ \\
\hline & & Magelona ?dakini & $2.8 \quad(0.5)$ & & Hiatula siliquens & $1.4 \quad(0.4)$ \\
\hline & & Colurostylis lemurum & $1.3(0.4)$ & & Colurostylis lemurum & $1.4(0.4)$ \\
\hline & & Nicon aestuarinensis & $1.1(0.4)$ & & Aonides oxycephala & $1.1(0.7)$ \\
\hline
\end{tabular}

Communities at 5 of the sites (AA, CB, EB, KP, PS) have been persistent in terms of their absolute species abundances, abundance rankings and species presence-absence over the first $5 \frac{1}{2} 2$ yr that they have been monitored (Table 1) and can, therefore, be regarded as highly stable. Despite the apparent overall persistence of the communities, there were significant within- and between-year differences in community structure 
(Table 2). Between-site differences, in terms of the patterns and magnitude of variability in community structure at any one time, were also apparent (Figs. 4 \& 5, Table 3). This implies that the balance of species within each community is being affected to different degrees by environmental and biological variables and that the changes are likely to have been dominated by the influence of local rather than geographical scale events. However, the occasional coincidence in the timing and magnitude of fluctuations in the total number of individuals and species at each site is indicative of harbour-wide scale events affecting community structure at each of the sites. For example, the low abundances and species diversities in the samples collected in February 1990 (Figs. 2 \& 3) coincided with a period during which summer water temperatures were $>20^{\circ} \mathrm{C}$ for at least 1 mo longer than in other years (Auckland Regional Council 1994).

The community at $\mathrm{CH}$ may be regarded as exhibiting an intermediate level of stability. The community exhibited long-term structural persistence in terms of species abundance rankings and species presenceabsence (Table 1). However, the significant differences in absolute species abundances recorded over the duration of the study were a reflection of the large population fluctuations which characterised the community at this site (Fig. 2). These population fluctuations, which primarily involved relatively short-lived polychaetes (e.g. Boccardia syrtis), while predictable with regard to the annual timing of their occurrence, were unpredictable in terms of their magnitude. Large recruitment and mortality events can induce physical, chemical and/or biological alterations in the habitat, which may lead to sequential changes in the ranking and dominance in a suite of other species, with potentially significant consequences on overall community structure. V. J. Cummings, R. D. Pridmore, S. F. Thrush \& J. E. Hewitt (unpubl.) have suggested, for example, that negative juvenile Macomona liliana/adult Boccardia syrtis interactions inhibit the recruitment of $M$. liliana and have contributed to the low abundances of the bivalve on Te Tau Bank (CH) in Manukau Harbour.

The perception as to whether a given community is persistent, or otherwise, will be dependent on scales of time and space (e.g. Sutherland 1981, Connell \& Sousa 1983, Connell 1985). With regard to time, it has been widely advocated (e.g. Davis \& VanBlaricom 1978, Connell \& Sousa 1983, Holland 1985) that statements about the stability of communities should be based on data collected over intervals of time greater than the life spans of the community dominants in order to avoid Frank's (1968) tautology. Sutherland (1990), however, has argued that the observation period should be sufficiently long that there is no doubt that no significant change in stability has occurred. This could be substantially shorter than the period required for the complete turnover of community dominants. The present study covered a period of $5 \frac{1}{2}$ yr (which is longer than the generation times of many of the dominant species in the communities), during which time we have been unable to detect significant changes in community stability at the sites.

\section{Effects of physical disturbance on community persistence and variability}

Shallow-water coastal and estuarine habitats are considered to be rigorous and dynamic environments, characterised by large predictable and unpredictable fluctuations in environmental variables and subject to continual disturbance. Such processes have widely been regarded as acting to prevent communities from developing to persistent stable states, except as an averaged condition over large temporal and spatial scales. Conversely, prolonged periods of high persistence stability in benthic communities have generally been attributed to physical environments that are relatively free of disturbance (e.g. Buchanan et al. 1986, López-Jamar et al. 1986).

Manukau Harbour is a dynamic and rigorous environment in terms of movements of water and sediments. The main flow is tidal and the degree of tidal flushing is relatively high as a result of the fact that a large proportion of the Harbour is emptied at every low tide (Heath 1975, Heath et al. 1977). Wind speeds exceeded 33 knots on an average of $69 \mathrm{~d}$ each year between 1987 and 1993, and 51 knots on an average of 3.6 d each year. Particularly windy years were 1987. 1988 and 1991, with wind gusts exceeding 33 knots on more than $80 \mathrm{~d}$. Both tidal cycles and wind-related meteorological events influence hydrodynamic conditions in the Harbour.

The prevailing wind direction over Manukau Harbour is from the southwest and west in all seasons, winds from the northeast are not uncommon (Fig. 1). The percent frequency of occurrence of winds from the southwest and west was $31 \%$ over the period 1987 to 1993. The greatest incidence of strong winds (>10 $\mathrm{m} \mathrm{s}^{-1}$ ) was also from these directions. The CANOCO results revealed a contrast between the 6 sites, reflecting the influence of mean wind conditions on community structure, with community structure at $\mathrm{AA}$ and $\mathrm{CH}$ apparently most affected by mean wind condition (Fig. 6). Wind-generated wave activity is likely to be consistently greater at $\mathrm{AA}$ and $\mathrm{CH}$, which are located in the eastern and northern reaches of the Harbour and exposed to the greatest wave fetch (see Fig. 1). The environment is likely to be considerably less dynamic at $C B$ and $E B$, located in the southwest- 
ern corner of the Harbour, and at PS, located close to AA, but afforded some protection from southwest and westerly wind-generated wave activity by a large sand-bank west of the site.

The most obvious impacts of variations in wind speed on the macrobenthic communities are likely to arise from wind-generated wave activity leading to increased turbulence and currents which, in turn, result in increased physical disturbance of the surface sediments. Smaller, surface-living fauna are likely to be buried or washed away by the action of the turbulent water. Only those larger or deeper-burrowing species or organisms otherwise adapted to withstand periodic erosion and burial are likely to survive. Wind will also contribute to desiccation stress at times of low tide, with potential effects on the survival of some species. Less obvious impacts are the effects of sedimentary and hydrodynamic conditions on the relative success of larval, juvenile and adult transport and settlement (Nichols \& Thompson 1985).

Nevertheless the general patterns of community types appear to have persisted at each site, with essentially the same set of species present from one sample period to the next, implying the presence of an underlying stability to community structure at each site. There is no evidence for either large-scale, consistent directional changes in community structure, or complete species turnover in any of the communities. Rather than acting to prevent communities developing to persistent stable states, the dynamic physical environment may have been conducive to the development and maintenance of stable communities. The passive transport of post-settlement stages through wind-generated wave activity may represent a major mode of recolonization following disturbance and will thereby assist in maintaining the persistence of the sand-flat communities (see Thrush et al. 1991).

\section{Conclusions}

Despite the dynamic physical environment and the large abundance fluctuations that characterize many of the species populations, the long-term ( $>5 \mathrm{yr}$ ) picture that emerges from this study is one of persistence stability. This overall persistence was evident despite marked differences in the structure characteristic of the macrobenthic communities at each of the sites (cf. the bivalve-dominated communities at $A A$ versus the polychaete-dominated communities at $\mathrm{CH}$ ). Furthermore, all the communities exhibited a degree of resilience, in that after different types and magnitudes of physical disturbance and major recruitment events, the communities tended to retain their original structure, rather than exhibiting large-scale, long-term changes in species composition and abundances. Although many species showed variable population numbers, their continuous presence in the samples further attests to their resilience. The tendency of the communities to retain recognisably similar structures over time, despite significant physical disturbance and dynamic biological events is further testimony to the resistance to change exhibited by these communities. Continued monitoring of the benthic communities in Manukau Harbour will reveal whether the magnitude of fluctuations in community structure continues, or whether there are trends away from the current persistent state.

Acknowledgements. Thanks to all the people who assisted with field and laboratory work during this long-term sampling programme. Special thanks to Rob Bell for preparing the wind data. The manuscript benefited greatly from the comments of Don Morrisey and 3 anonymous reviewers.

\section{LITERATURE CITED}

Auckland Regional Council (1994). Water quality survey of Manukau Harbour: sixth annual report. Auckland Regional Council Environment Technical Publication No. 37. Auckland

Begon, M., Harper, J L., Townsend, C. R. (1986). Ecology: individuals, populations and communities. Blackwell Scientific Publications, Oxford

Beukema, J. J. (1989). Long-term changes in macrozoobenthic abundance on the tidal flats of the western part of the Dutch Wadden Sea. Helgoländer Meeresunters. 43: 405-4.15

Beukema, J. J. (1992). Expected changes in the Wadden Sea benthos in a warmer world: lessons from periods with mild winters. Neth. J. Sea Res. 30: 73-79

Buchanan, J. B., Moore, J. J. (1986). Long-term studies at a benthic station off the coast of Northumberland. Hydrobiologia 142: 121-127

Buchanan, J. B., Brachi, R., Christie, G., Moore, J. J. (1986). An analysis of a stable period in the Northumberland benthic fauna - 1973-80. J. mar biol. Ass. U.K. 66: 659-670

Clarke, K. R. (1993). Non-parametric multivariate analyses of changes in community structure. Aust. J. Ecol. 18: $117-143$

Clarke, K. R., Green, R. H. (1988). Statistical design and analysis for a 'biological effects' study. Mar. Ecol. Prog. Ser. 46: 213-226

Cloern, J. E., Nichols, F. H. (1985). Time scales and mechanisms of estuarine variability, a synthesis from studies of San Francisco Bay. Hydrobiologia 129: 229-237

Connell, J. H. (1985). Variation and persistence of rocky shore populations. In: Moore, P. G., Seed, R. (eds.) The ecology of rocky coasts. Hodder and Stoughton, London, p. 57-69

Connell, J. H., Sousa, W. P. (1983). On the evidence needed to judge ecological stability or persistence. Am. Nat. 121. $789-824$

Davis, N., VanBlaricom, G. R. (1978). Spatial and temporal heterogeneity in a sand bottom epifaunal community of invertebrates in shallow water. Limnol. Oceanogr. 23: $417-427$ 
Dörjes, J., Michaelis, H., Rhode, B. (1986). Long-term studies of macrozoobenthos in intertidal and shallow subtidal habitats near the island of Norderney (East Frisian coast, Germany). Hydrobiologia 142: 217-232

Eagle, R. A. (1975). Natural fluctuations in a soft bottom benthic community. J. mar. biol. Ass. U.K. 55: 865-878

Field, J. G., Clarke, K. R., Warwick, R. M. (1982). A practical strategy for analysing multispecies distribution patterns. Mar. Ecol. Prog. Ser. 8: 37-52

Frank, P. W. (1968). Life histories and community stability. Ecology 49: 355-357

Heath, R. A. (1975). Stability of some New Zealand coastal inlets. N.Z. J. mar. Freshwat. Res. 9: 449-457

Heath, R. A., Greig, M. J. N., Shakespeare, B. S. (1977). Circulation and hydrology of Manukau Harbour. N.Z. J. mar. Freshwat. Res. 11: 589-607

Hewitt, J. E., McBride, G. B., Pridmore, R. D., Thrush, S. F. (1993). Patchy distributions: optimising sample size. Environ. Monit. Assess. 27:95-105

Hill, M. O. (1979). DECORANA - a FORTRAN program for detrended correspondence analysis and reciprocal averaging. Ecology and Systematics, Cornell University, Ithaca

Holland, A. F. (1985). Long-term variation of macrobenthos in a mesohaline region of Chesapeake Bay. Estuaries 8: 93-113

Holling, C. S. (1973). Resilience and stability of ecological systems. A. Rev. Ecol. Syst. 4: 1-23

Jones, A. R. (1987). Temporal patterns in the macrobenthic communities of the Hawkesbury Estuary, New South Wales. Aust. J. mar. Freshwat. Res. 38: 607-624

Legendre, P., Vaudor, A. (1991). The R package: multidimensional analysis, spatial analysis. Département de Sciences Biologiques, Université de Montréal

López-Jamar, E., González, G., Mejuto, J. (1986). Temporal changes of community structure and biomass in two subtidal macroinfaunal assemblages in La Coruña Bay, NW Spain. Hydrobiologia 142: 137-150

Nichols, F. H., Thompson, J. K. (1985). Time scales of change in the San Francisco Bay benthos. Hydrobiologia 129: $121-138$

Pimm, S. L. (1991). The balance of nature? Ecological issues in the conservation of species and communities. University of Chicago Press, Chicago

This article was submitted to the editor
Pridmore, R. D., Thrush, S. F., Hewitt, J. E., Roper, D. S (1990). Macrobenthic community composition of six intertidal sandflats in Manukau Harbour, New Zealand. N.Z. J mar. Freshwat. Res. 24: 81-96

Putman, R. J., Wratten, S. D. (1984). Principles of ecology. Croom Helm, London

Rachor, E., Gerlach, S. A. (1978). Changes of macrobenthos in a sublittoral sand area of the German Bight, 1967 to 1975. Rapp. P.-v. Réun. Cons. int. Explor. Mer 172: 418-431

Rahel, F. J. (1990). The hierarchical nature of community persistence: a problem of scale. Am. Nat. 136: 328-344

Sokal, R. R., Rohlf F. J. (1981). Biometry: the principles and practise of statistics in biological research. W. H. Freeman \& Co., New York

Stull, J K., Haydock, C. I., Smith, R. W., Montagne, D. E. (1986). Long-term changes in the benthic community on the coastal shelf of Palos Verdes, Southern California. Mar. Biol. 91: 539-551

Sutherland, J. P. (1981). The fouling community at Beaufort, North Carolina: a study in stability. Am. Nat. 118:499-519

Sutherland, J. P. (1990). Perturbations, resistance, and alternative views of the existence of multiple stable points in nature. Am. Nat. 136: 270-275

Tarazona, J., Salzwedel, H., Arntz, W. (1988). Oscillations of macrobenthos in shallow waters of the Peruvian central coast induced by El Niño 1982-83. J. mar. Res. 46: $593-611$

Ter Braak, C. J. F. (1988). CANOCO - a FORTRAN program for canonical community ordination by [partial] [detrended] [canonical] correspondence analysis, principal components analysis and redundancy analysis (version 2.1). Report LWA-88-02. Agricultural Mathematics Group, Wageningen

Thrush, S. F., Pridmore, R. D., Hewitt, J. E., Cummings, V. J. (1991). Impact of ray feeding disturbances on sandflat macrobenthos: do communities dominated by polychaetes or shellfish respond differently? Mar. Ecol. Prog. Ser. 69: $245-252$

Thrush, S. F., Pridmore, R. D., Hewitt, J. E. (1994). Impacts on soft-sediment macrofauna: the effects of spatial variation on temporal trends. Ecol. Appl. 4: 31-41

Underwood, A. J. (1989). The analysis of stress in natural populations. Biol. J. Linn. Soc. 37: 51-78

Manuscript first received: August 3, 1994

Revised version accepted: December 27, 1994 